\title{
Management Control System (MCS) as a Package Elements Influence on Organizational Performance in the Pakistani context
}

\author{
Shafique-ur-Rehman ${ }^{1}$, Rapiah Mohamed ${ }^{2}$, Hazeline Ayoup ${ }^{3}$ \\ ${ }^{1} \mathrm{PhD}$ Scholar, Tunku Puteri Intan Safinaz School of Accountancy, Universiti Utara Malaysia \\ ${ }^{2}$ Rapiah Mohamed, Tunku Puteri Intan Safinaz, School of Accountancy, College of Business, \\ Universiti Utara Malaysia \\ ${ }^{3}$ Senior Lecturer, School of Accountancy, College of Business Universiti Utara Malaysia, \\ Sintok Kedah Malaysia \\ Email: shafiqueurrehman2018@gmail.com
}

\begin{abstract}
This paper intends to demonstrate the relationships between the management control system (MCS) as a package elements with organizational performance. Many studies conducted and investigated the impact of the management control system (levers of control) and organizational performance and ignore the elements of MCS as a package. Pakistan textile industry faces a lot of issues regarding MCS as packages elements and due to these issue organizational performance reduced. Therefore, current study portray a framework that consists of some vital elements of control adopted from Malmi and Brown (2008) MCS as a package like planning control, cybernetic controls, rewards and compensation controls, administrative controls, and cultural controls which if empirically investigated would demonstrate the extent of by in Pakistan textile industry and how these controls generate better organizational performance. This suggests that the need for more explanation of Pakistani textile industry managers on the need to adopt better MCS practices as these practices lead to better organizational performance. Although the current paper is conceptual in nature thus, needs an empirical study to address in the light of resource-based view theory.
\end{abstract}

Keywords: Planning controls, cybernetic controls, rewards and compensation controls, administrative controls, cultural controls, organizational performance, MCS

\section{Introduction}

Organizational performance is compulsory for the existence of organizations in the market (Abu-Jarad, Yusof, \& Nikbin, 2010). Meanwhile, organizational performance means the effectiveness of organizations in the achievement of their goals (Henri, 2004). In organizations performance measured on the basis of two factors like financial performance and non-financial performance (Rehman, Mohamed, \& Ayoup, 2018). Therefore, 
organizations in measuring performance use different approaches. Some of the previous studies on organizational performance researchers only use financial performance in their study and ignore non-financial performance (Henri, 2006; Koufteros, Verghese, \& Lucianetti, 2014). Moreover, one of the studies suggests that non-financial performance is also compulsory for organizations to get long-term profitability (Rehman et al., 2018). In the current study, organizational performance will be measured in term of financial performance and non-financial performance.

The core purpose of MCS is to help organizations to achieve their objectives (Otley, 2003). The objective of MCS is to provide reliable and valid information that is valuable in planning, decision making, and in the evaluation of organizational performance (Merchant \& Otley, 2006). In the field of MCS Anthony (1965) is one of the most pioneers that present MCS framework. He suggests that when designing MCS in developing countries there is the need to review carefully culture and environment of developing countries. Culture and environment differently treated in developed and developing countries. It goes with constant MCS design without any modification it will not give benefit to organizations on the other words may be it disturbs organization effectiveness (Anthony, 1965).

MCS works in collective form and does not work properly in isolation and this argument supported by Chenhall (2003) and notify that in determining the components of specific MCS in segregation form have "the probable for the severe model under specification”. Moreover, MCS as a package Malmi and Brown (2008) to study in future research and consists of five major controls like planning control (PC), cybernetic controls (CBC), rewards and compensation control (RCC), administrative control (AC), and cultural control (CC). Moreover, it is well-known that studying MCS focus should be on broader package rather than studying MCS single element or practice like balanced scorecard or budgets (Fisher, 1998; Malmi \& Brown, 2008; Otley, 1999). Previous studies have addressed levers of control framework influence on organizational performance in the developed countries and ignore to study this relation in the developing countries (Henri, 2006; Henri \& Journeault, 2010; Lopez-Valeiras, Gonzalez-Sanchez, \& Gomez-Conde, 2016). One of the recent studies authors suggest that there is a need to investigate MCS influence on organizational performance other than developed countries (Bin-Nashwan, Abdullah, \& Obaid, 2017). This is a pioneer study that proposes hypotheses between MCS as a package all five elements with organizational performance. 
Pakistan textile sector is the biggest sector in manufacturing in Pakistan (Aftab, Hussain, Ahmad, \& Islam, 2017) and this sector is the backbone of the Pakistani economy. The textile industry in Pakistan faces issues regarding PC, CBC, RCC, AC, and CC that reduces their performance (Rehman et al., 2018). MCS is a significant resource that makes easy in decision making and control, and evaluation processes impacting organizational performance (Chenhall, 2005; Ittner, Larcker, \& Randall, 2003). In the current study, the resource-based view theory would be employed to investigate the relationship between elements of MCS as a package and organizational performance of the textile industry.

\section{Literature Review}

\section{A. Management Control System (as a package)}

MCS as a package consists of five dimensions like PC, CBC, RCC, AC, and CC (Malmi \& Brown, 2008). Even as the idea regarding MCS existed 30 years ago and current literature trying to study MCS holistic approach to a scant extent (Alvesson \& Kärreman, 2004). Nowadays, MCS playing a very important role and have influence organizational performance (Duréndez, Ruíz-Palomo, García-Pérez-de-Lema, \& Diéguez-Soto, 2016; Hanafi $\&$ Fatma, 2015). The basic objective of MCS entails helping organizations in the achievement of their objectives (Otley, 2003). MCS has the ability in the implementation of management plans, strategies, and process. Organizations develop MCS according to their requirements as well as wants and needs (Anthony, Govindarajan, \& Dearden, 2007). Although, it is wellknown that when studying MCS focus on the broader package instead of focusing on a single element like balanced scorecard or budgets (Fisher, 1998; Flamholtz, 1983; Malmi \& Brown, 2008; Otley, 1999). Moreover, studying MCS as a package it gives more reliable results instead of considering the single practice of MCS (Malmi \& Brown, 2008) and this argument supported by (Otley, 1999), considering the overall system in term of package give better results. MCS as a package typology that presented by (Malmi \& Brown, 2008), gives us more comprehensive results. However, some of the prior studies suggest that there is a need to study MCS as a package in future research (Dropulic, 2013, 2014).

\section{Planning Controls}

Planning controls refer to an ex-ante form of control to achieve the objectives of an organization (Flamholtz, Das, \& Tsui, 1985). Planning controls include action planning and long-range or long-term planning (Malmi \& Brown, 2008). Moreover, action planning refers to plan targets of an organization and actions for instant future, normally less than one year (Malmi \& Brown, 2008). Meanwhile, long-range planning refers to actions and objective for 
medium and long-range established, this kind of planning has more strategic focus in nature (Malmi \& Brown, 2008). Besides this, planning has a significant role for organizations in directing their employee's behavior and planning controls consider as a separate system in MCS as a package topology (Malmi \& Brown, 2008). Therefore, it is very important for scholars that they recognize whether planning controls done only to make decisions regarding activities that will be done in future.

\section{Cybernetic Controls}

Cybernetic controls refer to means "a process in which a feedback loop is represented by using standards of performance, measuring system performance, comparing that performance to standards, feeding back information about unwanted variances in the systems, and modifying the system's comportment" (Green \& Welsh, 1988). Moreover, cybernetic controls include budgets, FMS, NFMS, and HMS (Malmi \& Brown, 2008). Budgets have major significance for organizations and management use budgets to facilitate communicating as well as coordinating priorities (Abernethy \& Brownell, 1999). Meanwhile, the budget is used to facilitate low-level managers commitment as well as the priorities of these managers (Abernethy \& Brownell, 1999). Cybernetic control includes a master budget that refers to an extensive set of budgets in an organization that covers entire phases of organization operations (Hilton, 1999).

In cybernetic controls FMS also having a significant role and it is the general form of control that holds organizational employees accountable for specific financial measures like economic value added (EVA), profitability and activity, solvency, return on investment (ROI), and liquidity (Malmi \& Brown, 2008). FMS can be market-oriented or accountingoriented. Accounting oriented FMS can be defined in term of a ratio like ROI, return on net assets (ROA), return on equity (ROE), or in residuals terms like EVA, operating profit, residual income, and net income after taxes (Merchant \& Van der Stede, 2007). In cybernetic controls NFMS also having significant role and organizations don't ignore NFMS because it overcomes some limitations of financial measures (Malmi \& Brown, 2008). NFMS includes customer relations, relationship with the supplier, new product development, market share, and quality of product etc. In cybernetic controls, HMS refers to a mixture of both FMS and NFMS and HMS also called balanced scorecard (Ittner \& Larcker, 1998; Kaplan \& Norton, 1996, 2001; Malina \& Selto, 2001). However, some of the prior studies suggest that organizational performance improves to use cybernetic controls (Anthony, 1965; Hoque, 2004). 


\section{Rewards and Compensation Controls}

RCC in MCS as a package discussed as a separate system because RCC is very significant for the performance of an organization (Malmi \& Brown, 2008). Moreover, RCC knew as incentive system and it is a method for the improvement of performance of organizational members for wanted actions (Flamholtz et al., 1985). Likewise, RCC center of attention to motivate and enhance the performance of an individual as well as groups within the organization by attaining congruence within their objectives and activities (Bonner \& Sprinkle, 2002). Rewards include extrinsic as well as intrinsic rewards (Flamholtz et al., 1985 ) and extrinsic rewards mainly focused on management accounting research (Ittner \& Larcker, 2001). RCC is associated to cybernetic control systems and organizations also make available rewards and compensation for various others reasons like retain organizational individuals and provide confidence to cultural controls by giving rewards to that group (Malmi \& Brown, 2008). However, there is a need to think about RCC schemes in future (Malmi \& Brown, 2008).

\section{Administrative Controls}

Administrative controls refer to definite management control mechanism that used to direct managers or agents behaviors in the achievement of organizational objective and they also includes policy and structure frameworks (Chhillar, 2013). Meanwhile, administrative controls include three elements like policy and procedures, governance structure, and organization design and structure (Malmi \& Brown, 2008). Similarly, some scholars study organization design and structure (Alvesson \& Kärreman, 2004; Emmanuel, Otley, \& Merchant, 1990). Moreover, some of the scholars study governance structure (Abernethy \& Chua, 1996; Alias, Yaacob, \& Jaffar, 2017). Finally, some of the scholars study policies and procedures (Macintosh \& Daft, 1987; Simons, 1987). Organization design and structure can be changed manager of the organization and they can be categorized organization structure and design as control system (Malmi \& Brown, 2008) and this argument supported by Otley and Berry (1980), states that "certainly, organization can be viewed as a control process, occurring when group of people feels the need to co-operate in order to achieve purposes which require their joint actions". Governance structure within the organization direct employees behavior through accountability, monitoring, and formal line of authority (Malmi \& Brown, 2008).

Meanwhile, governance structure in the organization designed in different ways like researchers should not group them together instead study them how they linked with each 
other as well as with other controls (Malmi \& Brown, 2008). Policies and procedures are a bureaucratic approach to direct the behavior of organizational employees and also include policies and rules, and standard operating procedures (Macintosh \& Daft, 1987). Meanwhile, policies and procedures are a set of printed rules in the organization to provide direction to employees regarding overall the objectives of organization (Chhillar, 2013).

\section{Cultural Controls}

Culture refers to "set of beliefs, norms, and values that tends to be shared by its members and in turn influence their actions and thoughts" (Flamholtz et al., 1985). According to Malmi and Brown (2008) cultural control in an organization to control behavior consists in three ways. Firstly, the organization deliberately looks for as well as makes use of organization employees with the exact desired of values. Secondly, organizations as an alternative try to modify employee's values. Thirdly, convey a message to employees that what organization expect from them and what they do (Malmi \& Brown, 2008). According to Malmi and Brown (2008), the cultural control includes three elements like clan culture, symbol-based culture, and value-based culture. Clan culture means the reality that in the socialization process employees of the organization they have a tendency to bring into lines them with various cultural values (Ouchi, 1979). Moreover, in the organization clan controls have an influence on employees behavior and useful in the attainment of objectives of the organization, enhance unity among employees, and increase the level of commitment in employees to the clan (Singh, 2008). Symbol-based culture refers to a kind of culture that is demonstrated in visuals like the specific design of offices or special kind of employees uniform (Malmi \& Brown, 2008). Likewise, symbol-based culture refers to when organizations make observable expression e.g. specific building design, and specific dress code of employees (Schein, 1992). Value-based culture developed by (Simons, 1995) and refers to set of organizational definitions that formally communicated from senior managers and reinforced systematically to make available basic values, purposes, and also direction for their subordination (Simons, 1995).

\section{Conceptual Framework}

The framework below developed to express how the implementation of planning controls, cybernetic controls, rewards and compensation controls, administrative controls, and cultural controls could improve organizational performance. This is because MCS as a package linked to the strategic objectives of an organization; therefore, it follows only feasible control that could enhance organizational performance. 


\section{A. Planning Controls and Organizational Performance}

Planning controls broadly categorized into two like operational planning or shortterm planning, and strategic planning or long-range planning (Malmi \& Brown, 2008). Shortterm planning and long-term planning both argued to enhance organizational performance. One of the studies investigated the results that effective implementation of long-term planning enhances the performance of an organization (Ali, 2017; Babafemi, 2015). However, planning controls has been examined with different variables like objective and programs, formulation, competitive strategy, and implementation (Hanzlick \& Brühl, 2013; Khuong, 2003). Moreover, in MCS as a package topology planning controls separated from cybernetic controls (Malmi \& Brown, 2008). One of the prior studies, author adopted MCS as a package and conducted a study on German organizations and findings revealed that organizations focus on short-term planning as compared to long-term planning (Hanzlick \& Brühl, 2013). Hence, planning is a necessary component of MCS. Therefore, planning controls would be adopted to examine the relationship between planning controls and organizational performance. On the basis of above discussion current study proposed following hypothesis:

$\mathrm{HI}_{a}$ : There is a relationship between planning controls and organizational performance

\section{B. Cybernetic Controls and Organizational Performance}

Cybernetic control consists of four elements like budgets, financial measurement systems, non-financial measurement systems, and hybrid measurement systems (Malmi \& Brown, 2008). Cybernetic controls (budgets, FMS, NFMS, and HMS) argued to improve organizational performance. One of the prior studies investigated the relationship between budgets and organizational performance and findings elucidated that budgets enhance organizational performance (Pimpong \& Laryea, 2016). Likewise, some of the studies investigated the impact of budgets on organizational performance and budget improves organizational performance (Abdullahi, Kuwata, Abubakar, \& Muhammad, 2014; Elhamma $\&$ Taouab, 2015). Prior researchers show that balanced scorecard (financial measurement systems, and non-financial measurement systems) significantly enhance organizational performance (Mutai, 2015; Sahiti, Ahmeti, Sahiti, \& Aliu, 2016). Some of the researchers suggest that organizational performance improves by using various elements of cybernetic controls like budgets, FMS, NFMS, and HMS (Anthony, 1965; Hoque, 2004). On the basis of above discussion current study proposed following hypothesis:

$H 1_{b}$ : There is a relationship between cybernetic controls and organizational performance 


\section{Rewards and Compensation Controls and Organizational Performance}

Rewards and compensation consider in a separate head in MCS as a package (Malmi $\&$ Brown, 2008). Most of the studies investigated the relationship between rewards and compensation controls and organizational performance and findings elucidated that rewards and compensation have positive impact employees performance that ultimately enhances organizational performance (Hameed, Ramzan, \& Zubair, 2014; Mehran, 1995). Likewise, one of the studies investigated the impact of rewards and compensation on organizational performance and findings revealed that rewards and compensation enhance organizational performance (Katua, Mukulu, \& Gachunga, 2014). On the basis of above discussion current study proposed following hypothesis:

$H 1_{c}$ : There is a relationship between rewards and compensation controls and organizational performance

\section{Administrative Controls and Organizational Performance}

Administrative controls consist of organizational design and structure, governance structure, and policies and procedures in MCS as a package (Malmi \& Brown, 2008). Several researchers examined administrative controls in their studies but using its individual element like management innovation, board composition, board independence, centralization, and formalization (Fuzi, Halim, \& Julizaerma, 2016; Oluwatayo \& Amole, 2013). Moreover, some of them, therefore, attempt to increase variables to examine their impact on the previous variable to enhance it robustness (Ehikioya, 2009). Prior studies examined the influence of organization design and structure on the performance of organization and results elucidated that organization design and structure improve the performance of an organization (Akinyele, 2010; Alias et al., 2017; Lavie, 2006). Prior studies investigated the influence of governance structure on organizational performance and findings revealed that governance structure improves organizational performance (Haniffa \& Hudaib, 2006; Kiel \& Nicholson, 2003). In addition, some of the studies investigated policies and procedures influence on organizational performance and findings elucidated that policies and procedures enhance organizational performance (Buuni, Yusuf, Kiiru, \& Karemu, 2015; Merchant \& Van der Stede, 2007). Therefore, one of the studies examined the impact of administrative controls as a package with all elements e.g. organization structure and design, governance structure, and policies and procedures and findings revealed that administrative controls enhance organizational performance (Chhillar, 2013). On the basis of above discussion current study proposed following hypothesis: 
$H 1_{d}$ : There is a relationship between administrative controls and organizational performance

\section{E. Cultural Controls and Organizational Performance}

Cultural controls include clan controls (Ouchi, 1979), value base controls (Simons, 1995), and symbol-based controls (Schein, 1992) and these controls are regarded as a package when these controls are used to affect the behavior of employees (Malmi \& Brown, 2008). Some of the studies investigated the relationship between organizational culture and organizational performance and findings elucidated that organizational culture enhances the performance of an organization (Chilla, Kibet, \& Douglas, 2014; James Ng'ang'a \& Nyongesa, 2012). One of the recent studies investigated the influence of organizational culture on organizational performance and results revealed that organizational performance enhances with the influence of organizational culture (Nikpour, 2017). On the basis of above discussion current study proposed following hypothesis:

$\mathrm{H1}_{e}$ : There is a relationship between cultural controls and organizational performance

\section{Figure 1: Theoretical Framework}

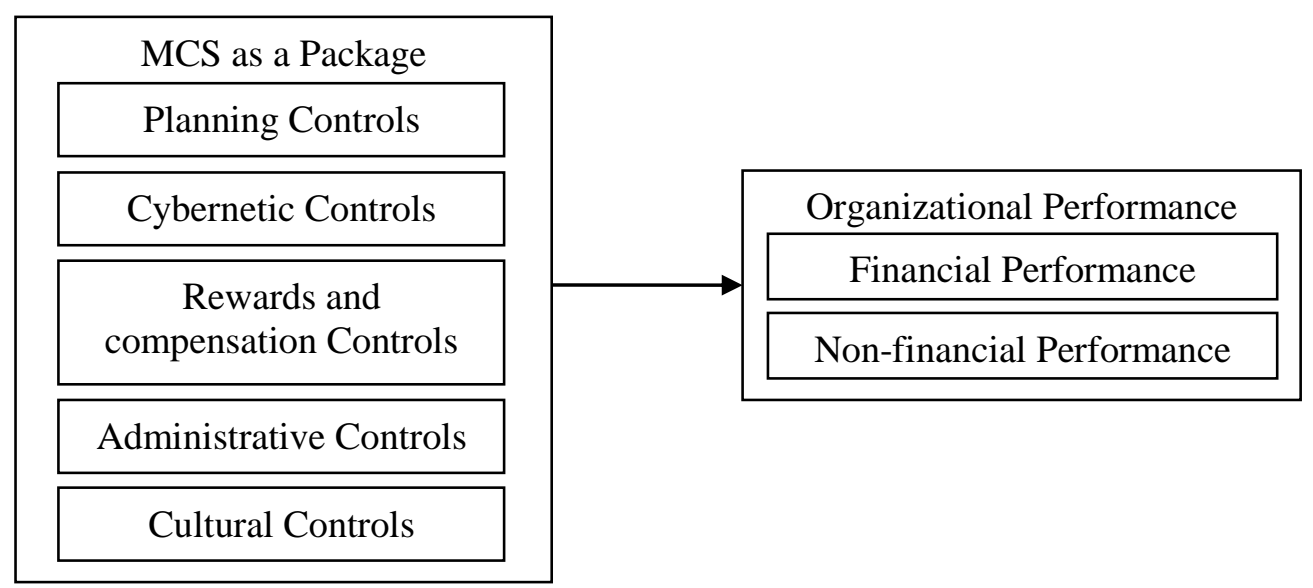

\section{Conclusion}

The current study put forth all elements of MCS as a package presented by (Malmi \& Brown, 2008) that consists PC, CBC, RCC, AC, and CC. We suggest that if MCS as package topology elements is adopted by Pakistani textile organizations it would enhance the performance of this sector. Planning controls include the flow of fresh ideas as well as better ways of doing things while cybernetic controls make possible of these ideas to provide finance. While administrative controls make possible the realization of planning controls ideas through the establishment of effective governance structure, organization design, and via better policy and procedures. While cultural controls sustain stability and cohesion within 
Pakistan Journal of Humanities and Social Sciences, 6(3), 2018

the organization. Thus, with the application of these controls in developing countries performance of organizations would be enhanced. Therefore, if empirical results conducted then these controls would recommend that these controls would enhance organizational performance. In future, both in developing and developed countries empirically tested this framework. 


\section{References}

Abdullahi, S. R., Kuwata, G., Abubakar, M. A., \& Muhammad, T. A. (2014). The role of budget and budgetary control on organizational performance: A case study of tahir guest house, kano state, Nigeria. International Journal of Innovative Research in Information Security, 4(2), 22-28.

Abernethy, M. A., \& Brownell, P. (1999). The role of budgets in organizations facing strategic change: an exploratory study. Accounting, organizations and society, 24(3), 189-204.

Abernethy, M. A., \& Chua, W. F. (1996). A field study of control system "redesign": the impact of institutional processes on strategic choice. Contemporary Accounting Research, 13(2), 569-606.

Abu-Jarad, I. Y., Yusof, N. a., \& Nikbin, D. (2010). A review paper on organizational culture and organizational performance. International Journal of Business and Social Science, 1(3).

Aftab, A., Hussain, A., Ahmad, Q. W., \& Islam, B. U. (2017). Causes of Workplace Stress in Textile Industry of Developing Countries: A Case Study from Pakistan Advances in Social \& Occupational Ergonomics (pp. 283-294): Springer.

Akinyele, S. T. (2010). Significance of strategic marketing to enterprise performance: An empirical analysis of Nigerian oil and gas industry. Global journal of management and business research, 10(6).

Ali, M. (2017). Effect of Firm Size on the Relationship between Strategic Planning Dimensions and Performance of Manufacturing Firms in Kenya.

Alias, N., Yaacob, M., \& Jaffar, N. (2017). Governance structure, corporate restructuring and performance. Polish Journal of Management Studies, 15.

Alvesson, M., \& Kärreman, D. (2004). Interfaces of control. Technocratic and socioideological control in a global management consultancy firm. Accounting, Organizations and Society, 29(3), 423-444.

Anthony, R. N. (1965). Planning and Control Systems: A Framework for Analysis [by]: Division of Research, Graduate School of Business Administration, Harvard University.

Anthony, R. N., Govindarajan, V., \& Dearden, J. (2007). Management control systems (Vol. 12): McGraw-Hill New York, NY. 
Pakistan Journal of Humanities and Social Sciences, 6(3), 2018

Babafemi, I. D. (2015). Corporate strategy, planning and performance evaluation: A survey of literature. Journal of Management, 3(1), 43-49.

Bin-Nashwan, S. A., Abdullah, N. S., \& Obaid, M. M. (2017). A review of literature in management control system (MCS) business strategy, and firm performance. International Journal of Management Research and Reviews, 7(2), 99.

Bonner, S. E., \& Sprinkle, G. B. (2002). The effects of monetary incentives on effort and task performance: theories, evidence, and a framework for research. Accounting, organizations and society, 27(4), 303-345.

Buuni, Yusuf, Kiiru, D. G., \& Karemu, G. (2015). Strategic plan implementation and organizational performance: a case of Hargeisa Water Agency in Somaliland. IOSR Journal of Business and Management (IOSR-JBM), Issue 11(Ver. II).

Chenhall, R. H. (2003). Management control systems design within its organizational context: findings from contingency-based research and directions for the future. Accounting, organizations and society, 28(2), 127-168.

Chenhall, R. H. (2005). Integrative strategic performance measurement systems, strategic alignment of manufacturing, learning and strategic outcomes: an exploratory study. Accounting, Organizations and Society, 30(5), 395-422.

Chhillar, P. (2013). Management control systems and corporate governance: a theoretical review.

Chilla, H. A., Kibet, Y., \& Douglas, M. (2014). Effects of Organizational Culture on Organizational Performance in the Hospitality Industry. International Journal of Business and Management Invention, 3(1), 1-13.

Dropulic, I. (2013). The effect of contingency factors on management control systems: a study of manufacturing companies in Croatia. Economic research-Ekonomska istraživanja(1), 369-382.

Dropulic, I. (2014). Design of management control systems-A study of joint stock companies in Croatia. Management: Journal of Contemporary Management Issues, 19(2), 157167.

Duréndez, A., Ruíz-Palomo, D., García-Pérez-de-Lema, D., \& Diéguez-Soto, J. (2016). Management control systems and performance in small and medium family firms. European Journal of family business, 6(1), 10-20. 
Ehikioya, B. I. (2009). Corporate governance structure and firm performance in developing economies: evidence from Nigeria. Corporate Governance: The international journal of business in society, 9(3), 231-243.

Elhamma, A., \& Taouab, O. (2015). Budgetary evaluation, environmental uncertainty and performance: case of Moroccan firms. American Journal of Service Science and Management, 2(1), 1 .

Emmanuel, C., Otley, D., \& Merchant, K. (1990). Accounting for management control Accounting for Management Control (pp. 357-384): Springer.

Fisher, J. G. (1998). Contingency theory, management control systems and firm outcomes: past results and future directions. Behavioral research in Accounting, 10, 47.

Flamholtz, E. G. (1983). Accounting, budgeting and control systems in their organizational context: theoretical and empirical perspectives. Accounting, Organizations and Society, 8(2-3), 153-169.

Flamholtz, E. G., Das, T., \& Tsui, A. S. (1985). Toward an integrative framework of organizational control. Accounting, organizations and society, 10(1), 35-50.

Fuzi, S. F. S., Halim, S. A. A., \& Julizaerma, M. (2016). Board independence and firm performance. Procedia Economics and Finance, 37, 460-465.

Green, S. G., \& Welsh, M. A. (1988). Cybernetics and dependence: Reframing the control concept. Academy of Management review, 13(2), 287-301.

Hameed, A., Ramzan, M., \& Zubair, H. M. K. (2014). Impact of compensation on employee performance (empirical evidence from banking sector of Pakistan). International Journal of Business and Social Science, 5(2).

Hanafi, E., \& Fatma, Z. (2015). The effect of the integration between levers of control and swot analysis on organizational performance: balanced scorecard approach. International Journal of Academic Research, 7(1).

Haniffa, R., \& Hudaib, M. (2006). Corporate governance structure and performance of Malaysian listed companies. Journal of Business Finance \& Accounting, 33(7-8), 1034-1062.

Hanzlick, M., \& Brühl, R. (2013). bManagement Control Systems as a package.

Henri, J.-F. (2004). Performance measurement and organizational effectiveness: Bridging the gap. Managerial Finance, 30(6), 93-123.

Henri, J.-F. (2006). Management control systems and strategy: A resource-based perspective. Accounting, organizations and society, 31(6), 529-558. 
Pakistan Journal of Humanities and Social Sciences, 6(3), 2018

Henri, J.-F., \& Journeault, M. (2010). Eco-control: The influence of management control systems on environmental and economic performance. Accounting, Organizations and Society, 35(1), 63-80.

Hilton, R. W. (1999). Managerial accounting. 4-th edition. McGraw-Hill Companies.

Hoque, Z. (2004). A contingency model of the association between strategy, environmental uncertainty and performance measurement: impact on organizational performance. International Business Review, 13(4), 485-502.

Ittner, C. D., \& Larcker, D. F. (1998). Innovations in performance measurement: Trends and research implications. Journal of Management Accounting Research, 10, 205.

Ittner, C. D., \& Larcker, D. F. (2001). Assessing empirical research in managerial accounting: a value-based management perspective. Journal of accounting and economics, 32(1), $349-410$.

Ittner, C. D., Larcker, D. F., \& Randall, T. (2003). Performance implications of strategic performance measurement in financial services firms. Accounting, Organizations and Society, 28(7), 715-741.

James Ng'ang'a, M., \& Nyongesa, W. J. (2012). The impact of organisational culture on performance of educational institutions. International Journal of Business and Social Science, 3(8).

Kaplan, R., \& Norton, D. P. (1996). Using the balanced scorecard as a strategic management system: Harvard business review Boston.

Kaplan, R., \& Norton, D. P. (2001). Transforming the balanced scorecard from performance measurement to strategic management: Part I. Accounting horizons, 15(1), 87-104.

Katua, N. T., Mukulu, E., \& Gachunga, H. (2014). Effect of reward an compensation strategies of the performance of commercial banks in Kenya. International Journal of Education and Research, 2(1), 1-20.

Khuong, L. H. (2003). The effects of long-range strategic planning and its impact on financial performance and growth of companies in the lime industry.

Kiel, G. C., \& Nicholson, G. J. (2003). Board composition and corporate performance: How the Australian experience informs contrasting theories of corporate governance. Corporate Governance: An International Review, 11(3), 189-205.

Koufteros, X., Verghese, A. J., \& Lucianetti, L. (2014). The effect of performance measurement systems on firm performance: A cross-sectional and a longitudinal study. Journal of Operations Management, 32(6), 313-336. 
Lavie, D. (2006). Capability reconfiguration: An analysis of incumbent responses to technological change. Academy of Management review, 31(1), 153-174.

Lopez-Valeiras, E., Gonzalez-Sanchez, M. B., \& Gomez-Conde, J. (2016). The effects of the interactive use of management control systems on process and organizational innovation. Review of Managerial Science, 10(3), 487-510.

Macintosh, N. B., \& Daft, R. L. (1987). Management control systems and departmental interdependencies: an empirical study. Accounting, organizations and society, 12(1), 49-61.

Malina, M. A., \& Selto, F. H. (2001). Communicating and controlling strategy: an empirical study of the effectiveness of the balanced scorecard. Journal of management accounting research, 13(1), 47-90.

Malmi, T., \& Brown, D. A. (2008). Management control systems as a packageOpportunities, challenges and research directions. Management accounting research, 19(4), 287-300.

Mehran, H. (1995). Executive compensation structure, ownership, and firm performance. Journal of financial economics, 38(2), 163-184.

Merchant, K. A., \& Otley, D. T. (2006). A review of the literature on control and accountability. Handbooks of management accounting research, 2, 785-802.

Merchant, K. A., \& Van der Stede, W. A. (2007). Management control systems: performance measurement, evaluation and incentives: Pearson Education.

Mutai, N. K. (2015). Influence of balanced scorecard on performance of safaricom kenya limited. School of business, university of Nairobi.

Nikpour, A. (2017). The impact of organizational culture on organizational performance: The mediating role of employee's organizational commitment. International Journal of Organizational Leadership, 6(1), 65.

Oluwatayo, A. A., \& Amole, D. (2013). Ownership, structure, and performance of architectural firms. Frontiers of Architectural Research, 2(1), 94-106.

Otley, D. T. (1999). Performance management: a framework for management control systems research. Management accounting research, 10(4), 363-382.

Otley, D. T. (2003). Management control and performance management: whence and whither? The British Accounting Review, 35(4), 309-326.

Otley, D. T., \& Berry, A. (1980). Control, organisation and accounting. Accounting, organizations and society, 5(2), 231-244. 
Pakistan Journal of Humanities and Social Sciences, 6(3), 2018

Ouchi, W. G. (1979). A conceptual framework for the design of organizational control mechanisms Readings in Accounting for Management Control (pp. 63-82): Springer.

Pimpong, S., \& Laryea, H. (2016). Budgeting and its impact on financial performance: The case of non-bank financial institutions in ghana. International Journal of Academic Research and Reflection, 4(5).

Rehman, S. u., Mohamed, R., \& Ayoup, H. (2018). Cybernetic Controls, and Rewards and Compensation Controls Influence on Organizational Performance. Mediating Role of Organizational Capabilities in Pakistan. International Journal of Academic Management Science Research (IJAMSR), 2(8), 1-10.

Sahiti, A., Ahmeti, S., Sahiti, A., \& Aliu, M. (2016). The Impact of Balanced Scorecard on Improving the Performance and Profitability of the Implementing Companies. Mediterranean Journal of Social Sciences, 7(4), 60.

Schein, E. H. (1992). Organizational Culture and Leadership. San Francisco: Josey-Bass. Google Scholar.

Simons, R. (1987). Accounting control systems and business strategy: an empirical analysis. Accounting, organizations and society, 12(4), 357-374.

Simons, R. (1995). Levers of Control (Harvard Business School Press, Boston). Google Scholar.

Singh, H. (2008). Watching (out for) each other: The role of clan controls in managing project teams. Paper presented at the Academy of Management Proceedings. 